\title{
Processing Conscientious Objector Claims: A Constitutional Inquiry
}

\author{
James B. White:k
}

$\mathrm{T}$ HIS ARTICLE WILL ANALXZE Selective Service System procedures for resolving a registrant's claim for conscientious objector classification ${ }^{1}$ and the nature of judicial review available after an adverse decision. I conclude that this process is constitutionally defective, and I propose the remedy of expanded judicial review of the merits of the conscientious objector claim. The passage of the Military Selective Service Act of 1967 has made several important changes in an older law, which was upheld by the Supreme Court despite its severe limitations on the rights of registrants, restricting those rights even further. ${ }^{2}$ Hopefully passage of the Act will provide occasion for the Supreme Court not only to scrutinize the changes themselves, but also to reconsider its position on the issues at stake when Selective Service classification decisions are challenged.

Under the new Act, judicial review is available only to a registrant who refuses to submit to induction when ordered to do so and who raises the defective classification as a defense in a consequent criminal proceeding. ${ }^{3}$ The scope of review is extremely narrow: The classification is to be upheld if it is supported by "any basis in fact." The Supreme Court has made clear that because a conscientious objector must demonstrate his sincerity, a local board can always deny his classification with a "basis in fact," at least if the registrant appears before the local board, simply by finding that his "appearance [is] one of unreliability." Thus, under

*A.B., 1960, Amherst College; A.M., 1961, LL.B., 1964, Harvard University. Assistant Professor of Law, University of Colorado.

1 There are two classifications for which persons conscientiously opposed to participation in war may qualify: "I-A-O," under which the registrant is available for service in the armed forces but only in a "noncombatant" position, 32 C.F.R. § 1622.11 (1967), and "I-O," under which the registrant is not obliged to enter the nilitary at all but performs civilian work contributing to the national health, safety, or imterest, under the supervision of his local board, $i d$. $\S 1622.14$. For a study of the administration of the conscientious objector law during World War II, see M. Stbiex \& P. JACOB, Conscription of Consctence (1952).

2 Military Selective Service Act of 1967, Pub. L. No. 90-40, 81 Stat. 100 (1967), 50 U.S.C.A. App. (Supp. 1967), amending 50 U.S.C. App. $\$ \$ 451-73$ (1964).

350 U.S.C.A. App. $\S 460$ (b) (3) (Supp. 1967), amending 50 U.S.C. App. $\$ 460$ (b) (3) (1964). See also Estep v. United States, 327 U.S. 114 (1946).

450 U.S.C.A. APP. $\S 460$ (b) (3) (Supp. 1967), amending 50 U.S.C. App. $₹ 460$ (b) (3) (1964).

5 Witmer v. United States, 348 U.S. 375,382 (1955). The Court has not expressly made clear whether the "appearance of unreliability" is subject to review, but federal courts seem to deny review completely, if demeanor evidence is relied on at all. See discussion in note 23 infra. 
present law a finding of insincerity is in practice simply not reviewable.

The procedures by which this administrative decision is reached, as first established by the old law and modified by the new, would give any lawyer pause: The registrant has no right to counsel, no right to present evidence of his own, no right to a meaningful hearing at any stage, and no right to a meaningful administrative appeal. ${ }^{6}$ Doubts as to the constitutionality of this procedure are increased when two important elements in the factual situation are considered-the first amendment character of the registrant's interest in his conscientious objector position, whether it be viewed as "religion" or as "speech," and the fact that notwithstanding the serious penal sanction, there is no sixth amendment trial of the merits of the claim. To me at least, it is clear-as I will later explainthat this procedure in this context, insulated as it is from judicial review, exceeds constitutional bounds.

More interesting than the final judgment as to constitutionality, however, is the way that judgment is expressed. The purpose of this paper is to analyze different legal theories that might be addressed to the statutory procedure, in the hope of determining which one most accurately and fully expresses the values at stake and which is most compatible with the fabric of our constitutional law. Although it seems that a requirement of greater review or relitigation could reasonably be based upon either the first or sixth amendment, further examination reveals difficulties with each that suggest the fifth amendment due process clause as the most appropriate basis for decision.

I

THE PROCESS OF DECISION AND REVIEW

\section{A. Prior to June 1967}

\section{A General View}

Both the procedure for determining a conscientious objector claim and the nature of one's riglit to challenge an adverse decision were developed under the Selective Training and Service Act of $1940^{7}$ and the Universal Mihtary Training Act and Service Act of $1948,{ }^{8}$ direct antecedents of present statutory law. Under that procedure, one's request for conscientious objector classification had to be made on a form that required rather full statement of beliefs and practices, along with extensive biographical information. ${ }^{9}$ Customarily, the local board would act on the basis of the form and supplementary material. If its decision was negative, the indi-

\footnotetext{
6 See text accompanying note 40 infra.

7 Ch. 720, \& 10, 54 Stat. 885 .

8 Ch. 62, 62 Stat. 604.

932 C.F.R. § 1620.11 (1967); Selective Service Form 150 (rev. 1959).
} 
vidual had a right to appear before the local board to explain his position, although he had no right to counsel, to a transcript, or to present evidence. ${ }^{10}$ From an adverse decision there was appeal as of right to the appeal board, although there was no right to hearing or appearance at that level; ${ }^{11}$ if there were a split decision at that level, or if the Selective Service System acquiesced, further appeal to the Presidential Appea] Board was possible, although again without any hearing rights. ${ }^{12}$ There was an important additional safeguard, available only to conscientious objector claimants: As part of the appeal to the appeal board, the statute required that a de novo hearing on the "character and good faith" of the registrant's objection be held by the Justice Department. On the basis of that hearing and "appropriate inquiry"-in practice an FBI investigation-the Justice Department was to make a recommendation which the appeal board had to consider but was free to reject. ${ }^{13}$ In practice, these hearings were usually held by private attorneys appointed as masters. This procedure at least gave a disappointed registrant the opportunity to present his case a second time to an officer distinct from the Selective Service System.

The statute declared that the classification decision thus reached by the Selective Service System was "final." At first, the Supreme Court seemed to take the statutory denomination of "finality" as conclusive and indicated that the only possible form of review was by habeas corpus after induction, which would apparently have subjected to review only the "jurisdiction" of the local board. ${ }^{15}$ One would be free to argue, for example, that one was not within the statutory age himits or, owing to foreign nationality and domicile, was not subject to the law, but not that the classification was "erroneous." It was later held that the policy of exhaustion of remedies underlying such restricted review would be satisfied if review were allowed before actual induction, where the registrant appeared for induction and refused to take the oath or otherwise participate in the ceremony of induction into the arned services..$^{10}$ Finally, the Court held that the test for review of a classification decision would be whether the local board's determination had "any basis in fact" on the theory that if it did not, it was deprived of "jurisdiction." "17 The question

10 See 32 C.F.R. \$§ 1624.1-.2 (1967).

1150 U.S.C. App. $\$ 460$ (b) (3) (1964), and 32 C.F.R. $\$ \S 1625.1-26.61$ (1967).

1232 C.F.R. $\$ \S 1627.1-8$ (1967).

1332 C.F.R. \& 1626.25 (1967).

14 See Act of June 24, 1948, ch. 62, tit. I, 62 Stat. 605, 620; Act of Sept. 16, 1940, ch. $720, \S 10,54$ Stat. $885,893$.

15 See Estep v. United States, 327 U.S. 114, 123 n.14 (1946); Falbo v. United States, 320 U.S. 549 (1944).

${ }^{18}$ See Billings v. Truesdell, 321 U.S. 542, 558 (1944). See also Wills v. United States, 384 F.2d 943 (9th Cir. 1967), petition for cert. filed, 36 U.S.L.W. 3108 (U.S. Oct. 25, 1967). 17 Estep v. United States, 327 U.S. 114, 122-23 (1946). 
whether there was a "basis in fact" or not was held to be a question of law for the court, not a jury question, and review was limited to consideration of the evidence actually before the local board so that the claim could not be litigated afresh with new evidence. ${ }^{18}$

\section{Conscientious Objectors}

The bearing of this test on conscientious objector claimants was made clear by a pair of cases in the early 1950's. Dickinson v. United States ${ }^{19}$ involved a registrant's claim of exemption as a minister which was denied by the local board. The Court held that once the ministerial registrant had satisfied the burden of establishing a "prima facie case" for exemption under the statute, his claim could not be denied solely on the basis of speculation or suspicion. There must "be some proof that is incompatible with the registrant's proof of exemption."20 The protection this case promised for the conscientious objector claimant proved fugitive indeed, however, in Witmer v. United States. ${ }^{21}$ In that case the Court indicated that it would uphold denial of a conscientious objector's claim, even where there was no specific evidence inconsistent with his claim, if the denial rested on a finding of insincerity based on the appearance or demeanor of the registrant. Dickinson was distinguished on the theory that personal sincerity is essential to the conscientious objector's claim, while the minister need prove only the fact that he is a minister, not his motives. A conscientious objector cannot make the sort of prima facie case available to a minister because he must prove that his objection is sincere, and the local board may find against him on that issue from his demeanor and bearing alone. ${ }^{22}$ Therefore, a central element of the merits of the conscientious objector's claim-the sincerity of his beliefs-was at least theoretically not judicially reviewable at all.$^{23}$ Review was himited to correction of procedural errors and, in those cases in whicls the local board or others

18 Cox v. United States, 332 U.S. $442,452-53$ (1947).

19346 U.S. 389 (1953).

$20 I d$. at 396.

21348 U.S. 375 (1955). In Witmer the local board did not rely on demeanor evidence for its conclusion of insimcerity, which was supported by some objective evidence, so the Court's remarks, however clear, are technically dicta.

$2 \mathrm{~s}$ "Here the registrant cannot make out a prima facie case from objective facts alone, because the ultimate question in conscientious objector cases is the simcerity of the registrant in objecting on religious grounds, to participation in war in any form. In these cases, objective facts are relevant only insofar as they help in determining the sincerity of the registrant in his claimed belief, a purely subjective question." Id. at 381 .

23 The Court in Witmer did examine the "objective facts" appearing in the record in order to determine whether there was a "basis in fact" for the denial of conscientious objector classification, and found such a basis in the radical inconsistencies in the registrant's claims-lie claimed exemption first as a farmer, undertaking to "contribute a satisfactory amount for the war effort," Witmer v. United States, 348 U.S. 375, 382 (1955), and when that failed lie claimed classification as a ninister, and only then as a conscientious objector. 


\section{in the appeal process indicated their reasons for classification, correction of errors of law so revealed. ${ }^{24}$}

But the Court indicated that it examined these facts only because there was no "indication anywhere in the record that his demeanor appeared shifty or evasive or that his appearance was one of unrehability." 348 U.S. at 382. Under this case it appears that a classification decision purporting to be based upon demeanor evidence is secure from any meaningful review. As Judge Friendly said for the Second Circuit in Corliss v. United States, 280 F.2d 808, 814, cert. deried, 364 U.S. 884 (1960): "It would seem to follow [from Witmer] that although denial of exemption nay be and often is supported by objective facts inconsistent with the claim, denial nuay also rest on a disbelief in the sincerity of the clnim, unaccompanied by any inconsistent facts, provided the disbelief is honest and rational." In Corliss there was no evidence of conduct inconsistent with the registrant's sympathies with the rehigion he professed, and his affiliation long antedated the induction call.

Corliss relied upon United States v. Simmons, 213 F.2d 901 (7th Cir. 1954), rev'd on other grounds, 348 U.S. 397 (1955), in which the problem of review of the issue of sincerity was clearly stated: "The conscientious objector claim admits of no such exact proof las the ministerial claim]. Probing a man's conscience is, at best, a speculative venture. No one, not even his closest friends and associates, can testify to a certainty as to what he believes and feels. These, at most, can only express their opinions as to lis sincerity. The best evidence on this question may well be, not the man's statements or those of other witnesses, hut his credibility and demeanor in a personal appearance before a fact-finding agency. . . . When the record discloses any evidence of whatever nature which is incompatible with the claim of exemption we may not inquire further as to the correctness of the board's order." 213 F.2d at 904. In this case the only evidence supporting a finding of insincerity was the rough chronological coincidence between his making a conscientious objection claim and his hability to military duty.

There are cases that in fact do impose a somewhat stricter standard of review. In Renupel v. United States, 220 F.2d 949 (10th Cir. 1955), it was held that speeding violations and a willingness to go hunting were not and did not constitute a "basis" for denial. Other cases imposing some fairly substantial standards of review are: Batterton v. United States, 260 F.2d 233 (8th Cir. 1958); Arnett v. United States, 205 F.2d 689 (10th Cir. 1953); Umited States v. Badt, 152 F.2d 627 (2d Cir. 1945), ceri. denied, 328 U.S. 817 (1946).

The Ninth Circuit has decided a series of cases that illustrate some of the difficulties with the operation of the Witmer standard of review. In Ashauer v. United States, 217 F.2d 788 (9th Cir. 1954), and Pitts v. United States, 217 1F.2d 590 (9tb Cir. 1954), the court reversed convictions where there was no objective evidence inconsistent with the clain and there was no express reliance by the draft board on cleineanor evidence as a basis for an attack on sincerity. But see White v. United States, 215 F.2d 782 (9th Cir. 1954). In Parr v. United States, 272 F.2d 416 (9th Cir. 1959), a conviction was reversed where the registrant did not appear before the local board which thus could not have relied upon demeanor evidence. Parr reveals an absurd consequence of stiff administration of the Witmer standard: A registrant might choose to avoid the hearing in order to deprive a local board of the opportunity of basing a decision on unreviewable grounds. In this case the court held that a remark by one of the registrant's spiritual leaders that he was "spiritually sick" and a "playboy" afforded no basis for a denial of the requested classification. The scope of review in this case is in fact very extensive; the court says of the Justice Department officer (the hearing officer's superior) who made an adverse recommendation, "We are as able as he to examine and evaluate that record." 272 F.2d at 422 .

For an interesting discussion of the general problem of the relevance of good character to conscientious objection classification, see Mansfield, Conscientionis Objection-1964 Term, 1965 Retigton \& PUB. Order 1, at 12-25, 47-59.

24 See, e.g., Sicurella v. United States, 348 U.S. 385 (1955). 
The Justice Department recommendation, based upon de novo hearing and an FBI report, substantially mitigated the harshness of this system. This stage was significant in part because of rigorous judicial enforcement of due process standards.$^{25}$ For example, while the registrant had no right to a copy of the complete FBI report, he did have a right to a "fair resume" of the report so that he could meaningfully answer any adverse representations contained in it, ${ }^{26}$ and he did have a right to a copy of an adverse recommendation made to the appeal board by the Justice Department. ${ }^{27}$ Where the Justice Department recommendation was based on an "error of law," the defect in classification so arising could be used as a defense in the prosecution for refusing to submit to induction. ${ }^{28}$

The major benefit of Justice Department participation was that it provided a de novo hearing on the merits of the claim before an impartial examiner not comected in any way with the local board or the Selective Service System. This was an effective appeal to a representative of the national government from a decision made by the local board, whose members were intentionally selected from the neighborhood, ${ }^{29}$ and who might be expected to be less than wholly sympathetic with or understanding of conscientious objector claims. ${ }^{30}$

\section{B. The New Law}

In June 1967, Congress passed the Military Selective Service Act of $1967^{31}$ which, together with the regulations it authorizes, makes such radical changes in the context of draft board decisions as to make reconsideration of the constitutional himitations upon them imperative.

The statute expressly adopts the scope of review and exhaustion standards that the Court had evolved under the silence of the old law: Errors in classification can be attacked only when raised defensively in a criminal proceeding for violating the Selective Service laws, and the scope of

25 In Sterrett v. United States, 216 F.2d 659 (9th Cir. 1954), it was held that denial of a Justice Department hearing voided a classification, even though the Justice Department reconmendation was only advisory and not binding. But of. Gonzales v. United States, 364 U.S. 59 (1960).

26 Simmons v. United States, 348 U.S. 397 (1955); Gonzales v. United States, 348 U.S. 407 (1955); see United States v. Nugent, 346 U.S. 1 (1953).

27 Gonzales v. United States, 348 U.S. 407 (1955); see United States v. Nugent, 346 U.S. 1, 6-7 n.10 (1953).

28 See Sicurella v. United States, 348 U.S. 385 (1955).

2050 U.S.C. APP. $\S 460$ (b)(3) (1965), as amended, 50 U.S.C.A. APP. $\S 460$ (b)(3) (Supp. 1967). Appointments are made "from the recounnendations made by the respective governors." Id. For an evaluation by the Selective Service Systen of local board treatment of conscientious objector claims, see note 86 infra.

30 See note 86 infra.

31 Pub. L. No. 90-40, 81 Stat. 100, 50 U.S.C.A. App. \$\$ 451-73 (Supp. 1967), amending 50 U.S.C. APP. §§ 451-73 (1964). 
review is limited to the Selective Service System's "jurisdiction" and therefore to determining whether a classification lias a "basis in fact."

Beyond this, the statute severely limits traditional prosecutorial discretion by requiring the Justice Department to "proceed as expeditiously as possible" with prosecutions under the Act upon request of the Director of the Selective Service System, or to notify both houses of Congress in writing as to its reasons for not doing so. $^{33}$ This shifts the exercise of discretion from the prosecutor to the Selective Service System. The Act even regulates court dockets, requiring courts to give "precedence" to cases arising under the Act, and stating that "such cases shall be advanced on the docket for imnediate hearing." ${ }^{\text {(84 }}$ Similarly, appeals to higher federal courts "shall take precedence over all other cases pending before the court to which the case has been referred." ${ }^{\prime 35}$

The new Act has also added a provision that drastically increases the consequences of an erroneous classification decision:

That, notwithstanding any other provision of law, any registrant who has failed or refused to report for induction shall continue to remain liable for induction and when available shall be immediately inducted. ${ }^{36}$

The President has issued an Executive Order complying with this section and directing the induction of any violators of the Act immediately upon their availablity. ${ }^{37}$ Therefore, a person who for conscientious reasons refuses to join the military despite an adverse classification is punished forever. After finishing a prison term for refusing induction one receives another induction order which, if refused, gives rise to another trial, conviction, and prison term, and so on, at least according to the terms of the statute and the regulation, forever. This relentless reinduction eliminates a registrant's last chance to assert to the court the sincerity of his objection, notwithstanding a contrary finding by the Selective Service System. Although the sincerity of one's behefs and the spirit in which induction was refused should surely be considered relevant at sentencing, such factors can have no effect under present law. If a judge is convinced that the registrant was wrongly classified and that justice requires a small

3250 U.S.C.A. App. $\$ 460$ (b) (3) (Supp. 1967). If this were read as an attempt to curtail the availability of habeas corpus jurisdiction, it would almost certainly be unconstitutional. See U.S. CoxsT. art. I, \$ 9, cl. 2; Moskowitz v. Kindt, 273 F. Supp. 646, 648 (ED. Pa. 1967).

3350 U.S.C.A. APP. $\$ 462$ (c) (Supp. 1967).

$34 I d . \$ 462(\mathrm{a})$.

36 Id.

36 Id. § 454(a) (emphasis added).

37 Exec. Order No. 11,360, 32 Fed. Reg. 9787 (1967), amending 32 C.F.R. \& 1631.8 (1967). 
sentence or no sentence at all, it is of no avail; at the end of that sentence, there is another. ${ }^{38}$

The most drastic change, however, is the complete ehmination of the Department of Justice from the appeal process. ${ }^{39}$ Now the conscientious objector can appeal only to the appeal board, before whom he has no rights of appearance, and then to the Presidential Board, if the appeal board is not unanimous in deciding his case or if the Selective Service System consents. He has no right to any hearings beyond his local board "appearance," where he lacks rights to counsel, to a transcript, or to present evidence. ${ }^{40}$ When this fact is coupled with the statutory directions restricting prosecutorial discretion and requiring immediate induction of those who have refused when "available," the conscientious objector is not only subject to life imprisonment for his persistence, but the sentence may be ultimately based upon an unreversible finding by his local board as to the sincerity of his beliefs.

There is a further concentration of injustice on the individual who is honestly opposed to participation in war: As a matter of policy the Selective Service System will frequently drop charges against one who has refused induction if he becomes willing to enter the service, and parole regulations provide fairly liberal terms for parole from prison into the military. ${ }^{41}$ It is nearly true that the only ones who must remain in jail are

38 This spectre will be realized, of course, only if the statute and regulations remain unchanged and are enforced for a substantial period of time, which might not be the case. Likewise it might be possible for the language to be interpreted in a manner that would avoid the result its plain meaning seems to compel.

3950 U.S.C.A. APP. § 456(j) (Supp. 1967), amending 50 U.S.C. ApP. § 456(j) (1964); Exec. Order No. 11,360, 32 Fed. Reg. 9793 (1967), rescinding 32 C.F.R. $\S 1626.25$ (1967).

40 See 32 C.F.R. \$§ 1624.1-.3 (1967).

41 The procedure for dropping charges is described in L. Hershey, LegaI, Aspects of Selectrve Service 61 (rev, ed. 1963). The policy is based on the theory that a "registrant's comphance with a local board order, even though belated, is generally more to the interest of the United States than a registrant's imprisonment." Id. A joint statement on the draft issued on December 9, 1967, by Attorney General Ramsey Clark and Lieutenant General Lewis B. Hershey, Director of Selective Service System, stated as follows with respect to the treatment of registrants who violate duties affecting their own status: "It has long been the law that a registrant who violates any duty affecting his own status (for example, giving false information, failing to appear for examination, or failing to have a draft card) may be declared a 'delinquent' registrant by his local draft board. Under consistent practice, information received by Federal law enforcement officials regarding a registrant's own draft status is turned over to his local draft board for appropriate action. When a person is declared to be a delinquent registrant by his local board, he may be reclassified and becoines subject to the highest priority for induction if otherwise qualified. If he fails to step forward for induction, he is subject to prosecution by the Department of Justice. This procedure is firmly established, approved by the courts, and has been followed since the enactment of the 1948 Selective Service Act, as well as under earlier selective service acts." N.Y. Times, Dec. 10, 1967, at 5, col. 1. This statement has been interpreted by 
those who are unfit and those whose objection-whether or not it meets the statutory standards for classification -is in fact sincere.

Certainly, when one recognizes that the interest asserted by the conscientious objector claimant is of the kind generally protected by the first amendment, and that his right to a classification honoring that interest is conclusively determined by an agency without meaningful judicial review and without sixth amendment trial even upon criminal prosecution, it seems not at all too strong to say that this system of classification and pumishment is an outrage upon fairness. ${ }^{42}$ The question I ask is: How should the federal courts treat this situation? What are the critical elements constituting the unfairness? How can the unfairness be defined and articulated in a way that leads to a decision most squarely based on the constitutional elements involved?

II

THE TOOLS OF ANALYSIS

\section{A. The First Amendment Argument}

The conscientious objector claimant who argues that he was misclassified by the Selective Service System is in a position to maintain that the misclassification interferes drastically with the free exercise of his religion, or with a parallel right also protected by the first amendment..3

the Justice Department to articulate a policy that registrants should not he prosecuted for nonpossession of draft cards (as they could be under 50 U.S.C. App. $\S 462$ (1964) and 32 C.F.R. \& 1671.1 (1967)) but should be reclassified I-A and given a chance to join the military. Colorado Daily, March 6, 1967, at 6, col. 4.

The parole policy is stated in Exec. Order No. 11,325, 32 Fed. Reg. 1119 (1967), adding $\S 1643$ to 32 C.F.R. New $\S 1643.10$ provides that parole thereunder to perform civilian work alternative to military duty is possible only for those who were classified I-O by the local board and refused to do such work. For the purposes of parole under this regulation, then, the original classification is absolutely binding. Presumably one would still be eligible for ordinary parole under 18 U.S.C. $\$ 4202$ (1964).

42 I lave described the way the classification and appeal process is supposed to work under the law, and conclude in this article that it is constitutionally defective. A study of how sample classification decisions were in fact made under the pre-1967 law makes this conclusion compelling. Rabin, Do You Believe in the Supreme Being? The Admintistration of the Conscientious Objector Exemption, 1967 WIs. L. Rev. 642.

This study shows that the "appearance" before a local board was in fact often a mere ten-minute harassment session, that local boards, relying on the appeal process to make the real decision, frequently denied routimely all conscientious objector claims, or the claims of those not affiliated with "peace churches," and that in practice the only meaningful opportunity to makeone's case was before the Justice Department liearing officer-the stage that has been abolished. Id. at 660,662 . The article also points out that local boards are frequently selected from among veterans' organizations, $i d$. at 667 , and makes much of the fact that their primary duty is to meet a manpower quota. Id. at 650,658 .

43 For a thorough and intelligent treatment of the various arguments for and against the existence of a first amendment right to conscientious objection, see Comment, The Conscientious Objector and the First Amendment: There but for the Grace of God..... 
But how can one argue from the involvement of the first amendment here to the conclusion that the present statutory procedure for decisionmaking offends the Constitution? In this form, the argument raises two questions: Is there a constitutional right to be a conscientious objector? If so, do existing procedures fail to accord this right adequate protection?

\section{Conscientious Objection: A Constitutional Right?}

The structure of the argument for constitutional protection of conscientious objection is found in purest form in the recent case of Sherbert v. Verner. ${ }^{44}$ There it was held that a state could not, under a general rule that conditioned unemployment compensation upon a willingness to work Monday through Saturday, deny compensation to a person who refused for religious reasons to work on Saturday. The important point is the reasoning the Court used: First the burden on the exercise of religion imposed by the state was analyzed, both with respect to the directness of the burden and its magnitude; then the state interest sought to be protected by this rule was analyzed and found insufficiently substantial or insufficiently in danger to warrant the burden on religion imposed in this instance. Although the standard for judging by this balancing process when state interests are sufficiently in jeopardy to warrant the first amendment interference is not stated with clarity, presumably it would be a more or less strong version of a "clear and present" danger or "grave and immediate" harm test. ${ }^{45}$

This balancing process supports an extremely persuasive argument that there is a constitutional right to conscientious objection, that is, that Congress cannot constitutionally force a man who is religiously opposed to participation in war to join the military or go to prison. ${ }^{46}$ The burden

34 U. CHr. L. Rev. 79 (1966). In United States v. Seeger, 380 U.S. 163 (1965), which purports to involve only statutory interpretation but which obviously has strong constitutional overtones, the Court held: "A sincere and meaningful belief which occupies in the life of its possessor a place parallel to that filled by the God of those admittedly qualifying for the exenption comes within the statutory definition." Id. at 176. This is a way of assuring that no discrimination among first amendment interests is made in favor of orthodox religion against an equally important, nontheistic interest, to be called, perhaps, "preferred speech." For the sake of simplicity I discuss the conscientious objector's position in terms of religion, but what I have to say throughout would apply equally, I believe, to any belief within the Seeger definition.

44374 U.S. 398 (1963). See also In re Jenison, 375 U.S. 14 (1963) (per curiam), on remand, 267 Minn. 136, 125 N.W.2d 588 (1963).

45 In the language of the Court the state interest must be "compelling" and the Court quotes with approval from Thomas v. Collins, 323 U.S. 516, 530 (1945): "Only the gravest abuses, endangering paramount interests, give occasion for permissible limitation." Sherbert v. Verner, 374 U.S. 398, 406 (1963).

48 I summarize here what seems to me the most persuasive argument. For other versions of this and other arguments, see Mansfield, supra note 22; Comment, supra note 43. 
on free exercise in such a case is as great and as direct as could be imagined: Not only is the person's practice of religion inhibited or prohibited, he is compelled to perform acts directly contrary to his religious conscience. ${ }^{47}$ And the state interest opposed to this extremely strong personal one is not weighty. It is certainly not the interest of national defense, since "service" by the small group of people involved in conscientious objector claims could not be essential to that endeavor. It is not the case that they must fight or the nation fall. ${ }^{48}$ The only adverse effect on state interest would be the loss of morale within the military if it were known or believed that some did not have to join the military or avoided their obligation too easily. This would be an indirect burden and extremely difficult to demonstrate as a matter of fact. ${ }^{40}$ In any event, the Selective Service System has made clear that the conscientious objector program run under statutory authority during World War II had no such adverse effect on morale. ${ }^{50}$

The Sherbert $v$. Verner analysis, then, supports a constitutional right of conscientious objection. This result is not substantially inhibited by prior Supreme Court decisions: Although it is commonly assumed that

47 Harlan F. Stone made this point after the end of World War I: "Viewed in its practical aspects, however, there may be and probably is a very radical distinction between compelling a citizen to refrain from acts which he regards as moral but which the majority of his fellow citizens and the law regard as immoral or unwholesome to the life of the state on the one hand, and compelling him on the other to do affirmative acts which he regards as unconscientious and immoral." Stone, The Conscientions Objector, 21 ColvM. U.Q. 253, 268 (1919). For once the distinction between feasance and nonfeasance in the law has some merit and would in fact provide an intelligible distinction between the conscientious objector and the polyganny cases. See Reynolds v. United States, 98 U.S. 145 (1878). Obviously this distinction works both ways: Not only is forced commission a greater burden on the individual, but conscientious nonfeasance is less likely to interfere with an important state interest than conscientious action.

48 One could argue that the national interest hardly requires the induction of those who are in fact conscientiously opposed to war, since they are, to say the least, unlikely to be good soldiers or contribute to military morale. On these grounds in fact the American Legion and the War Department both opposed repeal of conscientious objector classifications in 1940. 1 Conscrentious ObJection 88 (Selective Service System Special Monograph No. 11, 1950) [hereinafter cited as ConscIENTIOUS OBJECTION]. Lilsewise the military effort is at least financially impeded rather than helped by the cost of prosecuting and imprisoning violators. Id. at 138-39.

What is more, if registrants were conscientiously opposed to war in sufficient numbers to disrupt the inanpower recruitnent program, there would still be a serious constitutional question as to whether a majority of the citizens could by their power of vote impose military draft on a group of men conscientiously opposed to war. And, as a matter of democratic political science, such opposition could be considered a very meaningful "vote" by the relevant public on the issue of the draft.

49 And should the hostility of one group towards the rights of another be reason for cutting those riglits down in any way? Compare Feiner v. New York, 340 U.S. 315 (1951), with Terminiello v. Chicago, 337 U.S. 1 (1949).

50 See 1 Conscientious ObJection, supra note 48 , at 4. 
the Supreme Court has made clear that there is no such right, the basis for that view is far weaker than has been supposed.51 And no one should express surprise if the law in this field proved evolutionary.

The real obstacle to the establishment of this right by the Supreme Court is neither history nor logic, but politics. It is simply unlikely that the Supreme Court will attempt to define new areas of individual rights against the military in times of emergency or crisis, and it is particularly unlikely that such a right would be articulated in any but its narrowest possible form. The Court has with reason proceeded slowly in creating constitutional rights, and in this instance there are peculiarly difficult questions as to the scope of the right. Is it for religious objection only? Would not that violate the establishment clause? Is it for speech as well, or is "speech" not interfered with by the compulsion of actions inconsistent with thoughts, in the same way that "religious" beliefs and practices are? Must the objection be to all war? May it be to some war? To the use of ranks in the army? To other aspects of military life? The questions begin rather quickly to blend with the far harder and politically far more sensitive question of the constitutionality of the draft-one, it is fair to say, that will not soon again be squarely faced by the Court. ${ }^{52}$

\section{Does the Constitutional Right Compel Special Procedural Protection?}

The difficulty in defining this constitutional right in a way that expresses what is at stake in this statutory procedure is increased by the second question stated above: Even if there is a constitutional right to be a conscientious objector, how is that right not afforded adequate protection under existing statutory law and procedure? Does analysis of procedural defects gain anything from the hypothetical existence of a "constitutional right" to be a conscientious objector? Is there anything inherent in the right that prevents Congress from providing for its litigation before an administrative agency?

The sort of analysis we have employed to test for violations of the first amendment produces no very satisfactory result in answer to these procedural questions. The burden on free exercise of religion resulting from administrative rather than judicial determination of the existence of the right is obviously far less than the burden imposed by a flat denial of that right. And the burden is less "direct"-there is no formal prohibition of the exercise, and it is only as an incident to the adjudication procedure that there will be any burden at all, that is, only when the agency makes a "wrong" classification decision. In the procedural area, of course,

51 Couninent, supra note 43. See also the illuminating discussion of the case law in Mansfield, supra note 23, at 59-67.

62 See Selective Draft Law Cases, 245 U.S. 366 (1918). 
the state interest is also drastically reduced in scale. Now the issue is not whether persons will join the military but whether those who claim a conscientious objector classification which is denied have a right either to more extensive review than at present or perhaps to retrial before court or jury of the merits of their claim. Here the effects on both manpower and morale are bound to be minimal.

How can the balance be struck? The "balancing of interests" test for determining first amendment validity is siniply not a fruitful way to analyze the relative appropriateness of different institutions for adjudication. There does not seem to be a first amendment preference for court or jury trial rather than an administrative hearing. One does have a right under the present statute to appear before a local board-but no right to have counsel, to present witnesses or to obtain a transcript-and the classification procedure is controlled by procedural regulations. ${ }^{53}$ There is no assurance that a jury or judge will be "right" more often than a local board following this procedure. How then can the first amendment be used to articulate a preference for one institution for the adjudication of of first amendment rights rather than another?

(a) Judicial Review of "Constitutional F'act."-Two possible answers readily occur. The first focuses not on the first amendment character of the right asserted but on the fact that a constitutional right of any kind is involved. This line of attack, relying on the principles of Crowell $v$. Benson $^{54}$ and the Ben Avon case, ${ }^{55}$ would maintain that since the constitutional validity of the induction order depends upon whether or not the registrant is in fact a conscientious objector within the assumed constitutional definition, the merits of this claim are subject either to judicial redetermination or at least independent judicial scrutiny. Under this theory of "constitutional fact," there would be a constitutional preference for the judicial rather than the administrative forum, although the precise source of the preference may be less than clear: The due process clause of the fourteenth amendment is necessarily used in Ben Avon, which invalidated a state procedure, but the basis of Crowell seems to be pro-

5332 C.F.R. \$§ 1623.1-25.14 (1967).

54285 U.S. 22 (1932). This case held that the administrative procedure under the Longshoremen's and Harbor Workers' Act was constitutional but that the federal judicial power included examimation and if necessary relitigation of those facts that are "fundamental or 'jurisdictional' in the sense that their existence is a condition precedent to the operation of the statutory scheme." Id. at 54. In this case these facts were the existence of the employment relation and the occurrence of the injury on navigable waters of the United States.

55 Ohio Valley Water Co. v. Ben Avon Borough, 253 U.S. 287 (1920). This case, earlier than the Crowell case, lield that in a utility rate case where the rate was alleged to be so low as to be confiscatory, a state could not deny independent judicial judgment on that issue consistently with due process. 
tection of the federal judicial power, and certainly such institutional questions are at the heart of both decisions.

There are real difficulties in an attempt to found a resolution of our problem on these cases. Most obviously the use of this theory is impeded by the not extraordinarily fruitful dispute as to the extent to which the doctrine of these cases has remaining vitality. ${ }^{56}$ Far more importantsince it is clear that the ideas expressed and symbohzed by these cases have a great deal of hife, whatever their status as "authority"-is the diffculty arising from the immense generality of the principles involved. The doctrines of de novo hearing and independent judicial scrutiny of "constitutional fact" are obviously of great value as principles, and the roots of the principles are sound: A case such as $N g$ Fung Ho v. White ${ }^{57}$ holding that a claim of citizenship in a deportation proceeding must be submitted to judicial trial-is irrefutably right. But the broad principles of rehitigation or review of "constitutional" right are not malleable into a clearly defined doctrine whose consequences in different areas are susceptible of being understood and judged with clarity. The principles do not contain firm guides to their own elaboration. What is such a "constitutional" fact? How can one decide whether an alleged "error" is one within the constitutional "jurisdiction" of the agency and hence not subject to judicial redetermination, or whether it is a constitutional condition to the exercise of jurisdiction? If the independent judicial judgment test is used, how extensive must the required review be? Is review himited to the "basis in fact" test enough? Professor Jaffe's conclusion on this point is useful evidence of the generality of which I speak: "The dominant theme is that where 'constitutional fact' is in question the judiciary is less inclined to abide by the usual maxims of deference." "58 However' valuable an idea or accurate a description, this principle really does not lead to a clear solution of our particular problem. What is more, in the form stated it attributes nothing to the peculiarly first amendment character of the right involved here and surely that is central to any civilized response.

(b) First Amendment Preference for a Judicial Forum.-The other possible line of attack would be to say that the first amendment does indeed prefer some forums to others. And there are cases to support this

50 Compare the illuminating discussion of these cases in L. JAFFE, Judiciar Contror OF

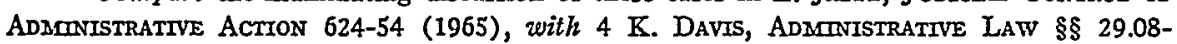
.09 (1958). The vitality of these doctrines in various contexts is discussed in Strong, The Persistent Doctrine of "Constitutional Fact," 46 N.C.L. Rev. 223 (1968). See also FPC v. Hope Natural Gas Co., 320 U.S. 591 (1944); St. Joseph Stock Yards Co. v. United States, 298 U.S. 38 (1936).

67259 U.S. 276 (1922).

68 L. JAFFE, supra note 56, at 652 (emphasis in original). 
broadly stated proposition: In Cantwell v. Connecticut $t^{50}$ for example, no weight at all is given the administrative determination of what constitutes a "religious" purpose. And the constitutional prohibition against prior restraint of speech results in-if it is not based on-complete rejection of the judgment of a licensing authority as to the quality of a speech or writing. ${ }^{60}$ Indeed in Jacobellis $v$. Ohio" ${ }^{61}$ there is an express "reaffirmance" by the two-man opinion of the Court of the principle that

69310 U.S. 296 (1940). Wolff v. Selective Service Local Bd. No, 16, 372 F.2d 817 (2d Cir. 1967), invalidates a procedure upon first amendment grounds, but this case does not bear directly on our issue. Wolf held that a court could review a classification prior to induction where it was alleged that the classification was designed to punish the registrant for the exercise of his right to free speech. Here exhaustion is inappropriate because it is the classification itself-not compelled military activity-that interferes with first amendment rights.

${ }^{60}$ Lovell v. City of Griffin, 303 U.S. 444 (1938), completely invalidated an ordinance requiring licenses for the distribution of literature. Accord, City of Bowling Green v. Lodico, 11 Ohio St. 2d 135, 228 N.E.2d 325 (1967); see Times Film Corp. v. City of Chicago, 365 U.S. 43 (1961); Kingsley Intl' Pictures Corp. v. Regents of the Univ, of the State of N.Y., 360 U.S. 684 (1959); Near v. Minnesola, 283 U.S. 697 (1931). The requirement of prompt and unfettered judicial determination of obscenity is articulated in Freedman v. Maryland, 380 U.S. 51 (1965) and enforced in Teitel Film Corp. v. Cusack, 390 U.S. 139 (1968).

There are other indications that the involvement of a first amendment interest will lead to more rigid protections more persistently enforced. For example, in Flack v. Municipal Court, 66 Cal. 2d 981, 429 P.2d 192, 59 Cal. Rptr. 872 (1967), the scizure of movie film allegedly obscene pursuant to an arrest but without a warrant was held invalid: "[T]he First Amendment compels more restrictive rules in cases in which the arrest and search relate to alleged obscenity." Id. at 991,429 P.2d at 198, 59 Cal. Rptr. at 878. Especially interesting is that the more persistent enforcement may take the form of expanded review: In Curtis Publishing Co. v. Butts, 388 U.S. 130, 158-59 (1967), Justice Harlan's opinion delivering the judgment goes out of its way to analyze and assess the evidence in the state court libel proceeding and determines that it is insufficient to support the finding of malice constitutionally required under the rule of New York Times v. Sullivan, 376 U.S. 254 (1964). See also Strong, supra note 56. And in Bond v. Floyd, 385 U.S. 116 (1960), the Court disregarded the finding of a state legislature made after hearing. In Dombrowski v. Pfister, 380 U.S. 479 (1965) a first amendment right is protected by the radical remedy of enjoining a state criminal prosecution. There seem to be no established criteria for determining when protections ought to be increased on first amendinent grounds, or how much, but the important point for us is that there is some connection, lowever ill-defined, between first amendment rights and procedures to protect them.

In Bond v. Floyd, 385 U.S. 110 (1960), the remedy is even stronger than might at first appear and of striking relevance to our situation: The Court indicates that wbile a state legislature may impose an oath requirement upon its members, this "does not authorize a majority of state legislators to test the sincerity with which another duly elected legislator can swear to uphold the Constitution." Id. at 132. Here where sincerity is put in issue, the remedy is not review or relitigation of that question, but declaration of its irrelevance. Although not stated, the obvious reason for insisting upon irrelevance is the difficulty of review of that issue which inakes abuse in its adjudication so likely. The difficulties inherent in adjudication of sincerity in the present less explosive context might not lead to the same drastic remedy, but surely an analogy between the situations can support requiring relitigation of that issue in prosecutions for refusing induction.

61378 U.S. 184 (1964). 
in "obscenity" cases as in all others involving the rights derived from the First Amendment guarantees of free expression, this Court cannot avoid making an independent constitutional judgment on the facts of the case as to whether the material involved is constitutionally protected. ${ }^{62}$

The Court here expressly rejects the adequacy of a "sufficient evidence" standard of review.

The Jacobellis principle seems promising, but despite the Court's apparent explicitness, it is not clear what sucl an "independent constitutional judgment" would involve in our case. ${ }^{63}$ Where the question is whether particular expressions are protected forms of speech or outside protection because obscene or libelous, the judgment can be made on a cold record. But the question of the sincerity of a registrant's beliefsrather than whether, assuming sincerity, the beliefs qualify under the law, a question already subject to not inconsiderable review ${ }^{64}$-could be judicially determined only upon a new hearing, and that is beyond what the Court has promised or performed. And sincerity or good faith is at issue in every case, especially as a result of the necessary vagueness of the standards for classification. ${ }^{65}$

It is worth repeating that both of the first amendment theories share a basic difficulty: The riglit to expanded review or relitigation is dependent upon the existence of a constitutional right to conscientious objection, and under all the circumstances it is not to be expected that the Supreme Court will directly establish the existence of a right to conscientious objection. And even the existence of such a right would not lead neatly and clearly to the resolution of the procedural problem to which this paper is addressed. The process of balancing interests used in first amendment cases simply does not work persuasively to prefer one institution to another.

\section{B. Right to Jury Trial}

If reliance on the first amendment is awkward because it does not itself express a preference for one forum rather than another, at least that

62 Id. at 190.

63 Nor is it clear what this will mean under Ginzburg v. United States, 383 U.S. 463 (1966), which held that punishment for the sale of marginally obscene literature may be justified by a finding that the defendant was engaged in the "sordid business of pandering," even where other sales of the same materials would not be prohibitable. Id. at 467. See generally Monaghan, Obscenity 1966: The Marriage of Obscenity Per Se and Obscenity Per Quod, 76 Yate L.J. 127 (1966).

64 E.g., United States v. Seeger, 380 U.S. 163 (1965); United States v. Stolberg, 346 F.2d 363 (7th Cir. 1965).

85 That sincerity is often the root issue is expressed by the title as well as the substance of an article co-authored by $T$. Oscar Smith, Chief of the Conscientious Objection Section of the Justice Department. Smith \& Bell, The Conscientious Objector Program-A Search for Sincerity, 19 U. PITT. L. REv. 695 (1958). 
difficulty is removed by reference to the sixth amendment which does guarantee a judicial trial with jury in all criminal proceedings. ${ }^{66}$ There is a certain appeal, perhaps more to the layman than the lawyer, in the argument that that right is infringed by a conviction where any fact as important as sincerity is conclusively decided by an administrative body.

In the case of the misclassified conscientious objector the deprivation of sixth amendment trial is almost total: The only jury issues are the existence of an induction order and a refusal to comply, and the court's function is limited to deciding whether or not the order has a "basis in fact." Wi7 When an order lias been disobeyed the only remnant of jury trial is the jury's power to acquit against the law. Argument designed to achieve that result, on the grounds that the defendant's objection is sincere, is of course improper. Given the statutory and administrative order directing continuous reinduction, the sincere and misclassified conscientious objector is liable to life imprisonment upon an unreviewable finding of insincerity by a three-man local board. This surely can be seen as a practical denial of the right to trial by jury.

There is considerable case authority that might be used to bolster an argument that there is a denial of jury trial here, althougli there is apparently none that directly supports that result. In the early case of Wong Wing v. United States ${ }^{8}$ it was held that the imposition of a term of lard labor upon Chinese aliens illegally in this country was constitutionally permissible only upon a sixth amendment trial (althougll deportation of aliens could constitutionally be effected by the administrative process). Similarly, in Kennedy v. Mendoza-Martinez, ${ }^{69}$ a statute purporting to deprive an American of his citizenship autornatically for remaining outside the jurisdiction of the United States in order to avoid military duty was held unconstitutional as an essentially penal statute imposing punishment without the safeguards that must attend a criminal prosecution under the fifth and sixth amendments.

\section{The Finality of Agency Findings in Prosecutions for Violating Agency Orders}

The main argument against requiring jury trial of the merits of the conscientious objection claim is of course that it is not the agency who

68 "In all criminal prosecutions, the accused shall enjoy the right to a speedy and public trial, by an impartial jury of the State and district where the crime shall have been committed ...." U.S. ConsT. amend. VI.

67 Cox v. United States, 332 U.S. 442 (1947).

68163 U.S. 228 (1896). $\mathrm{Ng}$ Fung Ho v. White, 259 U.S. 276 (1922), limited the power of Congress to provide for the administrative deportation of aliens by requiring that the claim of citizenship be given a judicial trial.

69372 U.S. 144 (1963). 
imprisons the defendant, and his imprisonment does not flow directly and necessarily from the fact found by the agency. He is not imprisoned for not being a conscientious objector but for disobeying an order to report for duty. The draft board does not punish him, but classifies him and issues an order based on that classification, and it is for disobeying that order that he is punished. As to that issue he has preserved to him inviolate the right of trial by jury. In Cox v. United States, ${ }^{70}$ sustaining these extreme limitations on jury trial and holding that the "basis in fact" test is for the court, not the jury, the Supreme Court said:

The concept of a jury passing independently on an issue previously determined by an administrative body or reviewing the action of an administrative body is contrary to settled federal administrative practice; the constitutional right to jury trial does not include the right to have a jury pass on the validity of an administrative order. ${ }^{71}$

The major case relied on in Cox to distinguish adjudication of the administrative matter from conviction for violating the resulting order was Yakus v. United States, ${ }^{72}$ which held that one convicted for violating OPA price regulations had no right to trial by jury on the issue of their propriety. Similarly, there is a line of authority that in a criminal proceeding for violation of an agency decision levying a fine or exacting a forfeiture ${ }^{73}$ or ordering deportation ${ }^{74}$ one has no right to jury trial on the merits of the agency decision.

The right to trial by jury in criminal cases has been expanding in recent years, as the right to a civil jury expanded earlier, ${ }^{75}$ and may lead to a rejection of the principle of Cox, Yakus, and related cases. For example, criminal jury trial has been made available to federal contempt defendants, ${ }^{76}$ and the Court has agreed to decide whether the jury guarantee applies to the states. ${ }^{77}$ Finally, for those eager to searcli out authority, there is the force of dissents by Justices Jackson, Frankfurter, and Black in United States v. Spector ${ }^{78}$ in which the Court refused to decide the

70 Cox v. United States, 332 U.S. 442 (1947).

71 Id. at 453 .

72321 U.S. 414 (1944). Yakus itself is of course distinguishable by the legislative nature of the regulation there involved and by the failure of the individual to exhaust administrative remedies. But it has come to have the symbolic meaning for which it is used in Cox.

73 Helvering v. Mitchell, 303 U.S. 391 (1938); Oceanic Steam Navigation Co. v. Stranahan, 214 U.S. 320 (1909).

74 United States v. Heikkinen, 240 F.2d 94 (7th Cir. 1957).

75 E.g., Dairy Queen, Inc. v. Wood, 369 U.S. 469 (1962).

70 Cheff v. Schnackenberg, 384 U.S. 373 (1966); see Note, 55 CaLIE. L. Rev. 608 (1967).

77 State v. Duncan, 250 La. 253, 195 So. 2d 142, prob. juris. noted sub nom., Duncan v. Louisiana , 389 U.S. 809 (1967).

78343 U.S. 169 (1952). See also Schwartz, Administrative Law and the Sixth Amend- 
constitutionality of a statute authorizing conviction of one who violates a deportation order as to which he has no riglit of judicial or jury review. Justices Jackson and Frankfurter were particular in basing their dissent on the denial of the right to jury trial.

There is a peculiar element in the present situation, however, that nuakes reliance on such a general movement in favor of jury trial unnecessary for the disapproval of Cox: Yakus and its ilk rest upon an assumption as to the nature of the relation between the individual and his government which is deeply inconsistent with the standards to which the government holds the conscientious objector. The Yakus theory seems to be this: When an adjudication is adverse to one's interests, one has a further and distinct interest in the continuation of the legal system which compels one to live with what one regards as the mistakes the legal system has made with respect to one's interests. The objectionable but "incorrectible" rule or decision is not disobeyed but complied with, because disobedience would be an attack upon the whole system of law and legal resolution of disputes, as well as upon the particular objectionable decision. What is more, if in a particular case a particular person fails in fact to perceive that he has a second interest in the system as a whole which requires that he be willing to live with certain mistakes it has made, we have little difficulty in saying that we will hold him to that perception as one he should have nrade.

As applied to the conscientious objector whose claims have been rejected by the draft board, this argument would take the following form:

You have made your case that you are entitled to a particular classification, and you have lost it, as so commonly happens in the world. Be a good loser, and comply with lawful orders issued upon the basis of your classification lawfully determined. Any disobedience to that order attacks not only the rightness of our determination-which like all human judgments may be wrong-but strikes at the root of all civil and legal order, and is properly punishable by law. There is no need for relitigation or jury determination of the rightness of our classification decision because that decision is not the basis for your punishment, except accidentally, nor is it an element in your crime. Your crime is failure to obey an induction order, which properly presents the only issue for jury determination.

Whatever the legal and logical virtues of such an argument-and they are not negligible - as a matter of practical fact it would simply make no sense to a person whose claim had been rejected. Why not? What exactly is the nature of its irrationality? I think it is this: The statute requires

ment: Malaise in the Administrative Scheme, 40 A.B.A.J. 107 (1954), urging full acceptance of the Spector dissent; Fraenkel, Can the Administrative Process Evade the Sixth Amendment? 1 SYRACUSE L. REv. 173 (1949). 
a person seeking conscientious objector classification to be totally committed to his conscientious stand in a way that is radically incompatible with his later becoming a "good loser." A person who, when asked, said that if Selective Service rejected his claim he would go into the army rather than go to jail, would obviously be far less likely to obtain a conscientious objector classification than one who said his opposition was so deep-seated that he would not fight under any conditions. ${ }^{79}$ It is hard to believe local boards have not asked sucli a question of registrants and considered a willingness to join the army if lawfully ordered to do so against the registrant. Indeed, the form upon which conscientious objection classification must be requested requires the registrant, inter alia, to "state whether or not your behef in a Supreme Being involves duties which to you are superior to those arising from any human relation." The Selective Service System has itself pointed out the "paradox" presented by the spectacle of one determined insincere by his local board spending a substantial term in jail in demonstration of his sincerity. ${ }^{81}$

Where the issue is sincerity-as it necessarily is with great frequency when the standards defining the substantive character of objection are so vague and uncertam ${ }^{82}$ - the registrant is put in an extremely unfair position in that he is asked to have a conviction that is of absolute primacy in his life in order to qualify for conscientious objector classification, but upon denial of that classification is told that if there is an error it is a mistake of the legal system with which he should be willing to live for the sake of the whole. A certain logic could lead to the conclusion that no conceivable system for adjudicating sincerity could be fair, since error is always possible and since the requirement that one have a conviction of absolute primacy dissolves the residual loyalty to the general system of law upon which we call to require that a person live with and obey a decision he regards as wrong. Obviously we could not tolerate an escape hatcli propped open by permanent nonjusticiability, and we must face the fact that whatever systen of adjudication we employ will make mistakes. Is there then a difference in fairness between a split trial, in which some facts are conclusively found by a possibly erroneous agency and others by a possibly erroneous court, and a unitary court trial in which

79 See, e.g., United States v. Hill, 221 F.2d 437 (7th Cir. 1955), where it was held against a registrant that he had once said, "If I have to go, I have to go." Id. at 440 .

80 Selective Service System Form 150 (rev, 1959). Prior to 1967 the statute expressly stated that the required belief involved "duties superior to those arising from any human relation." 50 U.S.C. APP. § 456(j) (1964). And complete dedication is still central to the idea of conscientious objection.

811 Conscientious OBJection, supra note 48 , at 138 . Of course, willingness to go to jail rather than join the army is not probative of the character of one's opposition: One can be sincere in holding a behief that does not qualify.

82 See cases cited note 64 supra. 
all relevant facts are found by the court system? Yes: If the procedure is a unitary trial, in every case the court system is punishing because it has found the registrant insincere or not qualified; under the split trial system there will be occasions where the court is persuaded of the sincerity of the individual and yet must punish him, notwithstanding this apparent injustice, because important principles-described above-require adherence to the finding of the three-man local board. Such a deviation from the norm of punishing only those proven to the satisfaction of the judicial system to be guilty of some substantial wrong can be justified only by reference to loyalties to the general legal system of a kind that this statute requires the conscientious objector claimant to deny. This unique unfairness would alone be good reason for insisting upon the unitary court trial of the merits of the objection claim and the crime of refusing induction.

\section{Jury Trial Policies and Conscientious Objection}

There are other, somewhat more traditional reasons that support the conclusion that jury redetermination of the conscientious objector claim upon trial for refusing induction is desirable and perhaps constitutionally required.

-The nature of the factual issue is not one particularly suited to administrative determination. No expertise is required to resolve the issue of sincerity of one's opposition to war and there are no complexities of the sort that would make jury determination inappropriate. Quite the reverse, the issue is simple, and its resolution requires those qualities of common sense, ability to assess lonesty, and familiarity with ordinary human behavior that are traditionally said to underlie the appropriateness of trial by jury. If there are questions that a jury is better able to decide than an agency, this would be such a one.

Further, the very conclusory quality of the question makes it one for whicl the jury is an appropriate institution. Like the ultimate net judgment as to negligence in tort law or reasonable self-defense or the question of insanity in criminal law, the question of the sincerity of conscientious objection under a necessarily vague statutory standard is one that properly belongs in the hands of the jury. And where opprobrium and punisliment are to be visited by the state upon a person who makes a moral claim for the rightness of his conduct, especially in a politically sensitive area, the jury plays its critical, traditional role as the intermediary between the individual and the state, both to protect the individual and to satisfy society's concern that such a nuatter be treated with all possible dignity and fairness. ${ }^{83}$

83 See, e.g., A Brtef Narrative of the Case and Tuial of John Peter Zenger (Am. 
Finally, the Selective Service System process of decisionmaking has certain exceedingly troublesome characteristics that tip the scales even further in favor of jury trial. First, the local board has or may have a serious conflict of interest in determining exemptions from armed service since its main function is that of obtaiming men for the military and meeting specific manpower quotas. ${ }^{84}$ Fair adjudication of conscientious objector claims is at least somewhat inconsistent with this duty unless the available pool of men is vastly greater than any expectable drain upon it.

More significantly, Selective Service System decisionmaking has apparently consisted in part of a conscious process of drawing and employing general policy lines of "leniency" or "strictness" rather than careful adjudication of individual cases. In describing its World War II experience the Selective Service System admits that local and appeal boards took what it calls a "strict line" with conscientious objector claimants, but maintains that the evils of this strictness were tempered by the leniency of the Presidential Appeal Board decisions. ${ }^{85}$ Whatever sense this may make as a matter of management (or even of fairness) from the point of view of the admimistrators, it says very little indeed for the quality of due process achieved by the System in its decisionmaking. Where extremely personal and subjective facts are at issue, the use of policy lines of this kind to determine appeals is foolish. It is not true-as this theory and practice must assume- that conscientious objectors can meaningfully be graded according to objective tests along a spectrum from those who most clearly qualify to those who most clearly do not. The use of policy lines even of extreme leniency will not produce improved results unless there are reliable criteria by which leniency is exercised.

The abolition of the Justice Department hearing on review will make the process of decision even more dangerously defective. Where the issue is sincerity, a rational reversal of an adverse finding is hardly ever possible on a cold record. For that class of cases in which really unjustified local board action is most bikely to be involved-where the sincerity of an applicant is wrongfully denied-review without reliearing is

ed. 1770); Nager, The Jury That Tried William Penn, 50 A.B.A.J. 168 (1964). If the argument be made that this purpose of jury trial is at odds with "the law," the answer is that the jury trial provision of the Constitution expressly provides for such "nonlegal" application or making of law. One could describe jury decisionmaking as a different "system of law" which is incorporated by the Constitution. See H. KaIven \& H. Zeiser, THe ArIertcan JURY 10 (1966).

84 See 50 U.S.C.A. App. $\$ 460$ (b) (3) (Supp. 1967), amending 50 U.S.C. App. $\$ 460$ (b) (3) (1964); 32 C.F.R. $\$ 1631$ (1967); Rabm, supra note 42, at 650, 658.

851 Conscrentrous OBJEction, supra note 48 , at 136-38, 144, 151-53. 
hardly worthwhile. ${ }^{86}$ Under the old law there was such a hearing before the Justice Department, whose recommendations were usually though by no means always followed, and whatever defects that system had, some effective review was possible on the question of sincerity. But it is perfectly clear that under the new law adverse determinations as to sincerity will not be subject to effective review within the Selective Service System.

Finally, although there can be no accurate measurement of "rightness" of past Selective Service decisions, one statistic does cast some doubt on the success of the program: About 12,000 persons did civilian work in heu of military duty as conscientious objectors in World War II; 2,000 of those whose claims were refused chose jail rather than the military, a rather large number of "failures." Another group of "failures" not measured would be those who were in fact opposed to war within the statutory definition but, upon misclassification, chose to obey an induction order rather than go to jail. At least it can be said that this record does not demonstrate success in the adjudication of these extremely difficult matters.

\section{A Constitutional Right to Jury Trial of the Merits of the Claim?}

Such an analysis of the relative merits of decisionmaking by the Selective Service System and by the sixth amendment trial may make us unhappy indeed with the former. The nature of the conscientious objector question is peculiarly appropriate for jury decision and peculiarly inappropriate for decision by the Selective Service System. The denial

86 The Selective Service System makes the startling and revealing assertion that "appeal board members very seldom knew or saw the registrants in question and their approach was therefore more impersonal," id. at 137, as support for the proposition that the appeal boards were somewhat more "hberal" than the local boards. The inembers of the Presidential Appeal Board-said by the System to be even more liberal-said in a report at the end of their first year: "Local boards and boards of appeal generally brought little sympathy to the consideration of these cases." Id. at 153. The Selective Service System makes clear the extraordinary difficulty that both the Justice Department and Selective Service lad in adjudicating these cases with all the aids of a de novo hearing and an FBI report. Id. at 144. The correction of local board decisions without the assistance of either, under present Jaw, will be impossible.

87 Id. at $117,260-66$. There were in addition to these 2,000 another 4,000 Jehovah's Witnesses who insisted upon ministerial exemption and would not accept a conscientious objector classification. The total number of Selective Service Act violators was about 16,000. Id. at 263. There were about 40,000 who served in the military as noncombatants.

The Selective Service System sensed its failure and at the end of the War proposed still another stage of internal review to ensure fairness-review of each case by National Headquarters prior to reporting it to a United States attorney for prosecution. Id. at 140. Such review is apparently now the practice, but the sole criterion by which the decision to prosecute is made is whether or not prosecution will be "successful." L. HeRsHeY, supra note 41 , at 61 . 
of review means that sixth amendment trial is limited to the narrowest issues. But by what process does the question of appropriateness become a matter of constitutional law? How can a constitutional principle be formed out of these considerations?

A way of focusing these questions is to ask wliether a registrant unsuccessfully making a claim other than that of conscientious objection -for example, for medical or hardship deferment-has the same right to sixth amendment trial. Distinctions can be made to justify denial of jury trial in such cases: Questions of hardship or fitness require some expert evaluation of health or family economics, for which a jury is not particularly adapted, and very little judgment as to the truthfulness or sincerity of the witness, for which it is. And hardship and fitness are areas in which general policies can properly be formulated and shift as circumstances cliange. When few men are needed, the Selective Service System can properly insist upon high standards of fitness and employ low standards of hardship, whereas in an acute emergency it might discard exemption of any person who can physically perform any useful task and deny any hardship exemption. More important, the Yakus theory that misclassifications are mistakes of the system with which one should be expected to live can be applied much more fairly to the hardship or fitness claimant than to the conscientious objector claimant. The former liave not been asked by the system to reject this theory by asserting the totality of their objection, and their claim is not inconsistent with entering the military under any circumstances as is the conscientious objector's claim. Finally, there is no claim of moral rightness by the hardship or fitness claimant, and thus the peculiar political appropriateness of jury decision in the conscientious objector case is $a b$ sent here. ${ }^{88}$

But it might still be objected that one lias not rationally justified the application of the sixth amendment by principles that clearly delineate when jury trial is required and when it is not. There is a danger in the use of such a constitutional right: It may prove an instrument both too blunt and too unwieldy to protect what needs to be protected without causing unnecessary difficulties elsewhere. Upon careful analysis of the particular facts of our situation, one can justify the invocation of the sixth amendment and limit its use by distinguishing the closest cases. But does the accumulation of factors calling for jury trial rise to a principle? If so, how can it be articulated? What consequences would the

88 One can ask the practical question whether any harm would result from permitting jury trial in all classification cases: After all, the registrant still must risk jail by violating an order if he is to raise the question, and this would undoubtedly inhibit any "flood of litigation." 
articulation of such a right here have for the vast body of state and federal administrative decisions in other areas? There is a danger that a special rule would be carved out for a single category of cases, an undesirable use of one of the basic guarantees of the Constitution. Finally, this use of the sixth aniendment would give no play to the fact that the conscientious objector's claim is of a first anendment complexion, surely a matter of great significance in the formulation of any principle dealing with this situation.

\section{Fifth Amendment Due Process}

In the preceding portion of this article I have attempted to distill from the situation with which we are concerned the key elements upon which a constitutional right could directly be founded-the first amendment character of the conscientious objector's position and the denial of sixth amendnient trial resulting fronı withdrawal of the most important questions from jury or court consideration. While either right can serve as a theoretical basis for requiring a significantly nore fair procedure for adjudication of conscientious objector claims, we have seen that in neither case is the result wholly satisfactory.

The problem with the use of the first amendment theory is obvious enough: The constitutional infirmity in procedure depends logically upon the existence of a first amendment right to conscientious objection that has not yet been estabhshed and very well may never be established. And, even if that right is recognized, the task is only half done: Existence of such a constitutional right does not necessarily make the estabhished procedural protections inadequate. Good argument is possible but it is not certain to be persuasive, and serious problems are raised as to the scope of the right recognized. The movement from premise to result does not have the efficiency that persuades.

Similarly, the sixth amendment trial argunent would correct specific unfair procedures by invoking an extremely general principle, whose ultimate limits are unclear. Although guaranteeing jury trial of the merits of any administrative order in a criminal action for its violation would create practical problems, they are less serious than those raised by the invocation of the first amendment. Only criminal cases could be directly affected by the jury guarantee-a fact that would inhibit the loosing of a flood of litigation by regulated businesses. And there are peculiar aspects to the conscientious objector's situation that make jury trial-or at least unitary trial of the merits and the criminal offenseuniquely appropriate. But, as we have seen, it is not at all clear that an analysis of the "appropriateness" is a proper way to support the right to jury trial. 
There is an additional difficulty with both theories: Neither is fully responsive to the extraordinary defects in the administrative decisionmaking process, although those defects obviously enter into any judgment that the present system as a whole is unconstitutional. Suppose the first amendment is rehed upon to require full relitigation of the merits of the first amendment clainl, or the sixth amendment to require jury trial, and then Congress passes a statute ensuring, as part of the administrative process, full hearing rights, right to counsel, a transcript, presentation of evidence, and an effective system of appeal to an agency organizationally distinct from the Selective Service System? Suppose that Congress provides for appeal to a federal judge sitting without a jury as part of the classification procedure? Such procedures still might be thought defective, but their institution would certainly be relevant to a judgment of constitutionality, and it is not clear exactly how they would be relevant to the operation of either of the theories discussed above.

The obvious alternative to either of these theories is the use of due process, the most flexible and delicate of constitutional tools. The fifth amendment due process reckoning would take account of the extreme deficiencies in the present administrative process and hold out at least the possibility of validating a revised and fairer system. One can readily see how due process reasoning could reflect the accumulation of factors explored above in support of sixth amendment trial, and in addition could adjust to a later alteration of these factors. Analysis of the appropriateness of jury trial and the inappropriateness of the present Selective Service System for decisionmaking can be reflected far more readily in the balancing of interests that traditionally underlies a due process adjudication than in the articulation of a "right" to jury trial, whicls has not hitherto been based upon that sort of particularized analysis. ${ }^{89}$

But can a due process adjudication reflect the first amendment elements in the situation? Here the matter is more difficult. One might well ask whether establishment of a first amendment riglit to conscientious objection would not be a prerequisite to a finding that the procedures

80 One recent and radical expansion of due process occurred in In re Gault, 387 U.S. 1 (1967), in which several basic rights-including rights to counsel and witness, which are denied a selective service registrant-were applied by the Court to juvenile proceedings notwithstanding the "noncriminal" nature of those proceedings. The decision was based in important part on the loss of liberty resulting from adverse adjudication. Id. at 27 . This case inay well lead to the imposition of similar requirements in civil commitment proceedings, for much the same reason. See People v. Potter, 85 IIl. App. 151, 228 N.E.2d 238 (1967); Commonwealth ex rel. McGurrin v. Shovlin, $210 \mathrm{~Pa}$. Super. 295, 231 A.2d 760 (1967) ; cf. Specht v. Patterson, 386 U.S. 605 (1967). These cases inark a heartening expansion of due process principles to cover restrictions of liberty not associated with criminal punishment. In none of these cases, however, was jury trial seen as an important issue. 
for its determination fail to meet due process standards. Is not the articulation of the substantive right to conscientious objection necessary before making the somewhat novel argument that the procedures for its litigation must meet due process standards more stringent than those involved in every administrative case?

Sherbert $v$. Verner supplies an answer. That case deliberately rejects the form of decision that first enunciates a "right" and then deduces consequences that flow from the existence of that right. Instead, the Court's decision follows an importantly different form, which seems to be closely modelled on traditional due process interest balancing: In this case it is clear that the Sabbatarian had a first amendment interest that either was or was not a right in the particular case depending upon low the balance was struck between it and the competing interest of the state. Why cannot the idea of a first amendment "interest," implicit in the use of such a balancing test, be used in the formulation and application of due process standards? The Court could accord special protections to a first amendment interest under the due process clause-for example, by giving the conscientious objection claim procedural protections not accorded a claim of economic liardship-without deciding whether or not the first amendment guarantees a right to conscientious objection. Thus, the Court could hold the present statutory limitations on judicial review unconstitutional and permit relitigation of the character and good faith of the registrant's beliefs without deciding that there was a constitutional right to be a conscientious objector in the event of a hypothetical congressional denial of that right.

This analysis would avoid the pitfalls of both the Crowell v. Benson theory (whicl depends upon the concept of "constitutional fact") and of the Jacobellis v. Ohio theory (which depends upon the existence of a first amendment "right") but would permit to flourish the strains in those cases that would require due process standards to reffect the nature and extent of a first amendment interest in a particular situation.

A similar attitude towards jury trial would be possible. A judgment could be made that the present procedure is constitutionally defective without necessarily declaring a right to jury trial of the merits of every administrative decision attacked in a criminal action, or even declaring a riglit to jury-as opposed to judicial-trial here. After all, one of the major arguments advanced above-that there is a special unfairness in the inconsistency demanded of the disappointed conscientious objector with respect to the absoluteness of his position-really goes less to jury trial specifically than to the need for a unitary trial of the merits of his conscientious opposition and of the violation of the order. In practice a jury trial flows fron this principle, since the unitary trial must 
obviously be a judicial one, and in the federal system this entails trial by jury. But this principal argument would be satisfied by a judicial trial on that issue, and the Court perhaps ought not foreclose itself from approving such a system if Congress were to institute it. Indeed, the holding of the invalidity of the present procedure could be very narrow, not even precluding the possibility that some version of a Justice Department hearing procedure of the type just abolished would satisfy the standards of due process, but making it clear that the present procedure is an unconstitutional deviation from those standards.

The Court has great flexibility here arising from the fact that it can supply a remedy for the unconstitutional procedure without the slightest disruption of any governmental agency, simply by permitting retrial of the merits of the conscientious objector claim. ${ }^{90}$ When and if the administrative procedure met due process standards it could withhold that remedy. The relitigation solution is completely within the judicial power and competence.

There is a final argument against this comfortable result: Due process may be the most flexible instrument of all-indeed its flexibility in the fourteenth amendment context has been a verbal and metapliysical marvel-but is it not also the lazy man's instrument? Is there not a real danger that the use of due process may obscure the fact that a decision is simply not principled but merely an ad hoc judgment? I think not in this case. If the elements at work in the due process reckoning are clearly identified and evaluated-as I hope they are in the analysis I have presented-the decision can become a part of a pattern of thought and decision through which new "rights" can evolve. There is a real place for a decision as raw as Rochin v. California ${ }^{91}$ in the law, and the nature and direction of the decision proposed here should be defined with considerably greater clarity than was the case there.

\section{CONCLUSION}

In the situation with which we are concerned the due process clause could be used to redress a serious procedural unfairness, recognizing the first amendment and sixth amendment elements in the judgment without placing the whole weight and prestige of the Constitution behind the creation of a "right" and without establishing general propositions of a kind that would invite polemic and fruitless disputation. The present procedure can be held unconstitutional with the easy remedy of permitting full relitigation within the federal courts, without providing a

90 As discussed above, text accompanying note 86 supra, merely to increase the scope of review is not an adequate remedy where the issue is as subjective as sincerity.

91 342 U.S. 165 (1952). 
constitutional blueprint for future legislation. The Court need not get into the legislative business itself in order to declare that a particular procedure fails to meet the standards of due process. But on no theory should the Court permit the present system to stand. 